Türk Coğrafya Dergisi
Sayı 64: 61-68, istanbul
http://www.tcd.org.tr

Hakemli Makale

Reviwed Article

\title{
Coğrafi bakış açısıyla ödemiş şehrinde kişiye karşı işlenen suçlar
}

\author{
Crimes against the person in the city Ödemiş with geographical perspective
}

\author{
Barış TAŞa , Fatih AKÇA ${ }^{b}$
}

a) Çankırı Karatekin Üniversitesi, Edebiyat Fakültesi, Coğrafya Bölümü.

b) Afyon Kocatepe Üniversitesi, Sosyal Bilimler Enstitüsü.

Geliş/Received: 20.01.2015 Kabul /Accepted: 04.05.2015

Sorumlu yazar/Corresponding author (F. AKÇA) fthakca@hotmail.com

\section{Öz}

Suç insanlık tarihiyle yaşıt, geçmişten günümüze var olan yaşayan ve toplumla birlikte değişen bir olgudur. Suç konusunda birçok farklı bilim dalı, kendi disiplinlerine özgü çalışmalar yapmışlardır. Coğrafya bilimi suçu, kendine özgü disiplin ve yöntemleriyle inceleyen bilim dallarından birisidir. Suç olayında coğrafi mekân önemlidir. Mekânda suçun meydana geldiği yer, sebep-sonuç ilişkisi ve dağılışı açısından coğrafyanın inceleme alanı içerisindedir. Bu çalışmada Ödemiş şehrinde işlenmiş suç türlerinin dağılışı, kişiye karşı işlene suçların diğer suçlar içindeki yeri, şehrin coğrafi özellikleriyle ilişkilendirilmeye çalışılmış ve şehrin coğrafi özelliklerinin kişiye karşı suçlar üzerindeki etkileri değerlendirilmiştir. Çalışmada İzmir il Emniyet Müdürlüğü, Ödemiş ilcçe Emniyet Müdürlüğü, Ödemiş Belediye Başkanlığı ve Tüik'ten elde edilen istatistiksel verilerden faydalanılmıştır. İstatistiksel veriler gruplandırılıp sadeleştirilmiş, Coğrafi Bilgi Sistemleri (CBS) yardımıyla suç veri tabanı oluşturulmuştur. Yapılan analizler sonucunda Ödemiş şehrindeki kişiye karşı suçlar farklı bakış açılarıyla ele alınmıştır. Ödemiş şehrinde kişiye karşı işlenen suçların diğer suçlara göre daha fazla yer tuttuğu tespit edilmiştir. Bunun yanı sıra şehirde kişiye karşı işlenen suçların yaz aylarında ve ticari hareketliliğin fazla olduğu mahallelerde yoğunlaştığı görülmüştür. Ödemiş şehrinde kişiye yönelik suçlarla sosyo-ekonomik yapı arasındaki ilişkiler belirlenmeye çalışılmıştır.

Anahtar Kelimeler: Ödemiş, suç coğrafyası, kişiye karşı suçlar.

\section{ABSTRACT}

Crime is a changing phenomenon with the community which is coeval with the history of humanity and lives from past to today. Many different science branches about crime works on their own disciplines. Geography science is one of the science branches which analyzes crime with distinctive disciplines and methods. Geographical location in which a crime hoppens is important. The place where the crime occurs is in the domain of geography in terms of the cause-effect relation and distribution. In this study, the distribution of crime types, the appointment of the crime, being committed against a person, in other crimes, its impact on the city's tried to be associated with geographic features and crimes against the person of the geographical faetures of the city were evaluated. Statistical data whic was derived from Izmir Provincial Security Directorate, Ödemiş District Police Department, Ödemiş Mayorship and TSI. The statistical data has been grouped, simplified and the crime database has been created whit the Geographic Information System (GIS). In the result of analysis, crimes whic are against the person in Ödemiş have been handled from different perspectives. The crimes against the person have been found the take up more space in Ödemiş, compared to the other crimes. Besides the crimes committed against the person enhance in summers and in the neighborhood where commercial activities are. In the Ödemiş town, the relationship between the socio-economic structure and the crimes against the person has been tried to determine Keywords: Ödemiş, geography of crime, crimes against the person

\section{GíRiş}

Suç, evrensel bir olgudur. Toplumların tarihsel gelişim süreci incelendiğinde, her tür sosyal yapıda suçun her zaman var olduğu görülür. Evrenselliğinin yanında suçun bir başka niteliği de göreceli oluşudur. Suçu oluşturan fiiller toplumdan topluma ve zaman içerisinde değişiklik gösterebilirler. Bir ülkedeki kanunlara göre suç olarak kabul edilen bir olay, başka bir ülkede suç teşkil etmeyebilir (Dönmezer, 1994). 
Suç geçmişten günümüze var olan, toplumla birlikte değişen ve yaşayan bir olgudur. Her toplumun kendi değer ve yargılarını oluşturan sosyo-kültürel baskı ve kontrol mekanizması vardır. Bu baskı ve kontrol mekanizması her toplumda var olan kanun koyucu tarafından gerçekleştirilmiş, ceza yaptırımı uygulanmıştır. Toplumların yaşayan bir olgu olması, toplumu oluşturan bireylerin sürekli değişmesine neden olmuştur. Toplumun değişmesi ve bireylerin değişimi birbirlerinden farklıdır. Toplumdaki değişmelerin hızı ile bireylerin değişme hızı her zaman aynı değildir ve bireyler değişen koşullara her zaman ayak uyduramazlar. Bazen de tam tersine bireyler toplumun genelinden önce gelişebilirler ve değişebilirler. Aradaki dengesizlik çeşitli sorunların kaynağını oluşturur. Bu sorunların en önemlilerinden biri de suç olgusudur (Sargın ve Temurçin, 2011).

Suç olgusunun-olayının mekânla ya da coğrafi ortamla sıkı bir ilişkisi söz konusudur. Sonuçta suç olarak nitelendirilen olaylar, belirli bir mekân parçasında ve insanlar tarafından gerçekleştirilir. Bu açıdan suçlar, coğrafyanın da ele aldığı konular arasında yer alır. Bu çalışmada bireye ya da kişilere yönelik işlenen suçlar coğrafi bakış açısıyla değerlendirilmeye, analiz edilmeye çalışılacaktır. Çalışma alanı olarak seçilen Ödemiş şehri, Ege bölgesinin en büyük şehri olan İzmir'in bir ilçesine merkezlik yapan yerleşme durumundadır (Şekil 1). Yerleşme tarihi oldukça eski olan Ödemiş şehri nüfus büyüklüğü bakımından, İzmir'in taşra ilçeleri arasında Menemen ve Torbalı'dan sonra üçüncü sırada yer almaktadır. İzmir'e uzaklığı 110 km olan Ödemiş, yerel nitelikte bir halk pazarı merkezidir. Bu durum şehirde suç oranlarının artışında etkili olmuştur. Şehirde halk pazarının kurulduğu Cumartesi, tüm suç kategorilerinde en yüksek suç oranlarının gerçekleştiği gün durumundadır. Halk pazarında yoğunluğun arttığı yaz ve sonbahar aylarında da suç oranlarının artış gösterdiği gözlenir.
Çalışmada istatistksel analiz ve gözlem yöntemleri kullanılmıştır. Yapılan analizlerde, büyük bölümü Ödemiş ilıçe ve İzmir il Emniyet Müdürlüklerinden alınan 2012 yılı suç istatistiklerinden faydalanılmıştır. Bu istatistik veriler sadeleştirildikten sonra Coğrafi Bilgi Sistemleri yardımıyla değerlendirilmiş konuya ilişkin farklı haritalar üretilmiştir. Bunun yanı sıra halk pazarının kurulduğu Cumartesi günlerinde pazaryerinde çeşitli gözlemler yapılarak fotoğraf ve videolar çekilmiştir.

\section{SUÇ - COĞRAFYA İLiŞKISi}

Kriminoloji, hukuk, sosyoloji, coğrafya, ekonomi, antropoloji, şehir planlama, mimari gibi pek çok bilim tarafından incelenen suç kavramı, gittikçe kalabalıklaşan ve karmaşıklaşan dünyada daha önemli bir hal almıştır. Suç toplumsal bir olay olduğu için çeşitli bilim dallarının inceleme konusu olmuştur. Her bilim dalı kendisine özgü özellikleri nedeniyle değişik suç tanımları yapmışlardır (Sargın ve Temurçin, 2011).

Türkiye'de suç konusunda en fazla çalışma sosyoloji ve kriminoloji bilimleri tarafından yapılmıştır. Kriminolojinin, suçlu davranışları ve toplumun bu davranışa tepkisini inceleyen bilim dalı olması, suç kavramı ve suç türlerini farklı şekillerde ele almalarına olanak sağlamıştır (i̇çli, 2013). Sosyolojiye göre suç, bir sapma davranışı olmakla birlikte, yazılı hukuk tarafından da yasaklanmış, karşıı̆ı̆ında yaptırım öngörülen eylemlerdir. Suç, toplumun bütününü ilgilendiren önemli bir sosyal problemdir. Sosyal bilimlerin birçoğunun uğraşı alanına giren suç konusu; suçun aydınlatılması yönüyle bazı doğa bilimlerinin de ilgisi içindedir. Bu nedenle suç, farklı bakış açılarına göre değişik şekillerde tanımlanmaktadır. Buna göre hukuki manada suç, kanun koyucu tarafından cezalandırılması öngörülen fillerdir (Dönmezer, 1994; İçli, 2013).

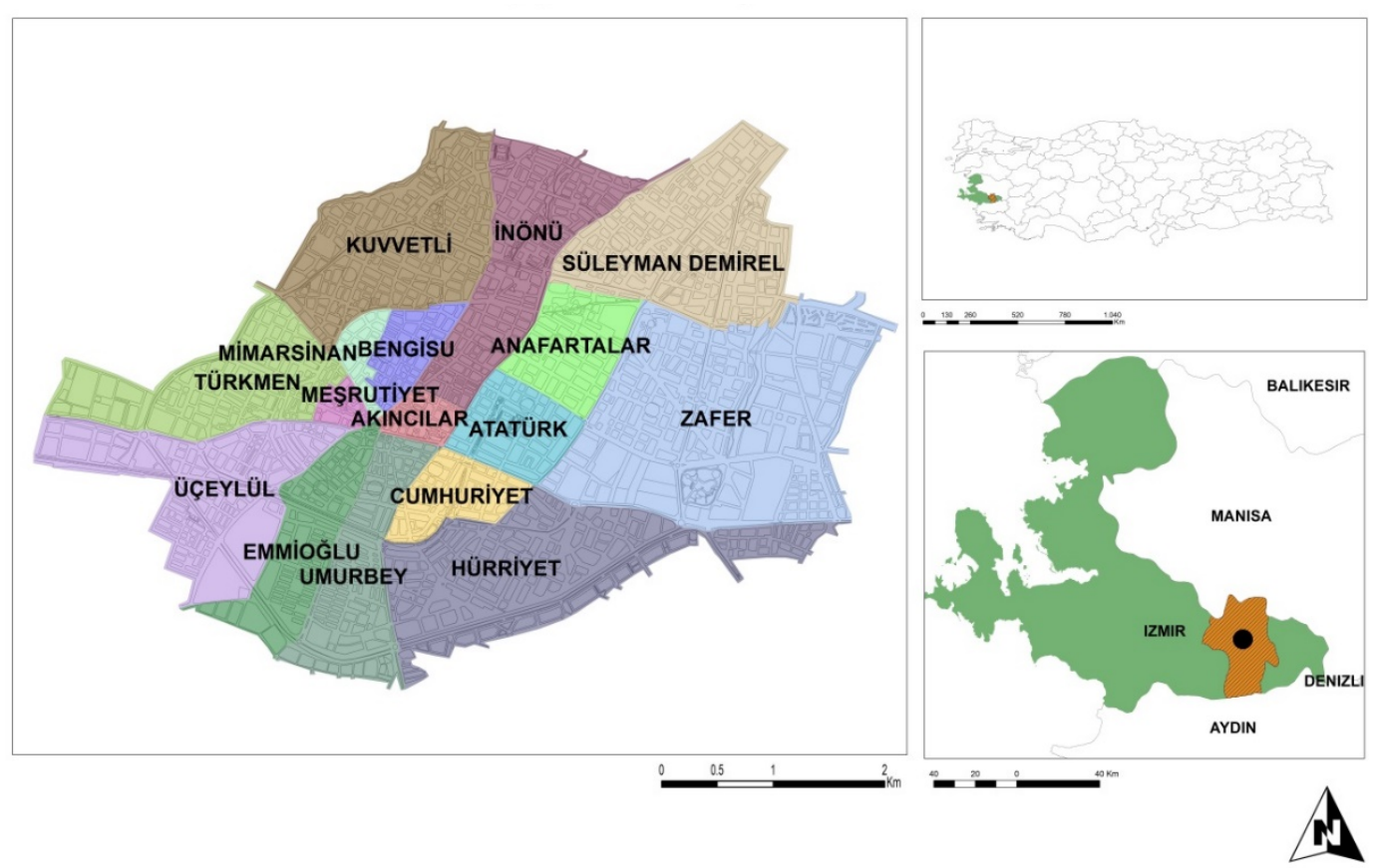

Şekil 1. Ödemiş Şehri'nin lokasyon haritası.

Figure 1. Location map of Ödemiş district. 
Siyasi bakış açısına göre suç, güçlü gruplar tarafından yasalara konulan ve yasadışı olarak etiketlendirilerek, cezalandırılması öngörülen bir ölçüttür. Psikolojik bakış açısına göre, suç bir davranış problemi olarak, topluma kötü uyumun bir sonucudur. Bu insan ruhunun derinliklerinden gelen ve dış dünyada somutlaşan bir istemdir (Erem, 1997). Sosyolojik bakış açısına göre suç, bir toplumda toplumsal normları ihlal eden çoğunlukçu değerlere aykırı biçimde tezahür eden davranış biçimidir (İçli, 2013). Bununla birlikte suçun en yaygın iki tanımı, hukuki ve sosyolojik olanlarıdır. Hukuki açıdan suç, yasa tarafından yapılması yasaklanan ve yapılması halinde eylemcinin ceza ile karşılaşacağı her türlü eylemdir. Sosyolojik açıdan suç ise, toplumsal düzenin korunması amacıyla baskılanması gereken anti sosyal davranıştır (İçli, 2013). Genel olarak suç, topluma zarar veren veya tehlikeli olduğu kanunlarla kabul edilen tavır, davranış, hareket ve eylemler bütünüdür (Karakaş, 2005).

Suç, işlendiği mekân, zaman ve etkilendiği dinamiklerle coğrafî bir olaydır. O hem sosyal hem de mekânsal yapının farklılaşması ile ortaya çıkmaktadır (Yılmaz, 2006). Coğrafyayı, "Mekânda birbirini etkileyen faktörlerin incelenmesi" (Tümertekin, 1984) olarak da tanımlamak mümkündür. Tabiatıyla suç diğer bilimlerin olduğu gibi, coğrafyanın (beşerî coğrafyanın) da çalışma konusu olmaktadır (Aliağaoğlu, 2007). Suç sosyal, ekonomik, politik, fiziksel, psikolojik şartlar ve çevrenin etkileşimi ile ortaya çıkan bir olgudur. Suç olayında coğrafi mekân önemlidir. Diğer bir ifadeyle suç boşlukta meydana gelmemektedir (AppaiheneGyamfi, 2003). Herhangi bir suçun dört farklı boyutu vardır. Bunlar yasa, suçlu, mağdur ve yerdir. Yer, zamanla birlikte ve yasa, suçlu mağdurun etkileştiği ve suçun meydana geldiği bir lokasyondur (Herbert ve Hyde, 1985). Davidson, suç olayında mekânın etkisini açıklarken, "suçlu üçgeni"(Davidson, 1999) kavramını kullanmaktadır. Söz konusu üçgenin iki köşesinde suçlu ve mağdur bulunurken son köşesinde ise yer yani mekân bulunmaktadır (Aliağaoğlu, 2007).

Mekânı oluşturan özelliklerin suç olgusu üzerinde etkisi farklı şekillerde ortaya çıkabilmektedir. Doğal coğrafi özellikler mekânı oluşturan elemanlardır. Çok sayıda bileşene sahip olan doğal faktörleri, yeryüzü şekilleri, iklim ve diğer coğrafi özellikler olarak sıralamak mümkündür (Aliağaoğlu, 2007). Örneğin insanoğlunun oldukça karmaşık olan davranış yapısındaki değişimlerin, havanın değişkenliği ve kısa süreli sıcaklık ile birleşimi; trafik kazaları, sokak kargaşaları, cinsel suçlar ve aile içi şiddet olayları ile ayrıca birleşmiştir (Andris 1997). Soğuk iklim şartlarının mala karşı işlenen suçlarda, sıcak iklim şartlarının ise daha çok kişilere karşı işlenen suçların artmasına neden olduğu düşünülmektedir (Özey, 2004).

Suç üzerinde etkili olan fizikî faktörlerin yanı sıra, beşerî faktörlerin etkisi de önemli bir yer tutmaktadır. Sosyal çevre ve şartları, eğitim durumu, ekonomik durum, aile yapısının yanı sıra kentleşme, sanayileşme, işsizlik, göç, yoksulluk, din, sosyal ve ekonomik bunalımlar vb. faktörler suç ve suç türleri üzerinde etkili olan beşerî faktörler arasında yer almaktadır. Örneğin şehir içi arazi kullanımı özellikleri beşerî faaliyetlerin türünü belirlemektedir. Bu nedenle ticaret mekânlarındaki suç tipleriyle, eğlence fonksiyonunun geliştiği alanlar ve oturma alanlarındaki suç tipleri arasında farklılıklar ortaya çıkmaktadır (Aliağaoğlu, 2007).

Türk Ceza Kanununa göre suçlar 10 ana başlık altında toplanmaktadır ve bu ana suçların kendi içlerinde alt dallara ayrıldığı görülür. Bunlar; vatana ihanet suçları, hürriyete karşı suçlar, devlet yönetimine karşı suçlar, adliyeye karşı işlenen suçlar, kamu düzenine karşı işlenen suçlar, kamu görevine karşı suçlar, kamu esenliğine karşı suçlar, genel ahlak ve aile düzenine karşı işlenen suçlar, kişiye(şahsa) karşı suçlar ve mala karşı suçlar şeklindedir (İçli, 1999). Bu çalışmada kişiye (şahsa) karşı işlenen suçlar, Ödemiş şehri örneğiyle ele alınacaktır.

Alüvyal toprakların bulunduğu sahalar tarih öncesi çağlardan beri insanların arazi kullanımı açısından en çok ilgilendikleri alanlardır. Ayrıca bu yerlerdeki alüvyon çevrenin iklim, bitki örtüsü, toprak örtüsü, özellikleri gibi fiziksel özelliklerinden hemen etkilenip bunu yüzey şekillerine yansıtırlar (Gözenç, 1978). Ödemiş şehri de Türkiye'nin önemli alüvyal sahaları içerisinde yer alan Küçük Menderes grabeninin doğu kesiminde yer alır. Verimli arazilerin varlığı, bu sahayı tarih boyunca yerleşmelerin yoğun olarak yer aldığı bir yer haline getirmiştir. Ödemiş şehri, Küçük Menderes havzasının yukarı bölümünde Bozdağlar'ın güney eteklerinde yer almaktadır. Küçük Menderes havzasının kuzeyinde doğu-batı yönünde yaklaşı $170 \mathrm{~km}$. boyunca uzanan Bozdağlar, Birgi Beldesi'nin kuzeyinde $2159 \mathrm{~m}$. yüksekliğe ulaşmaktadır (Vardar, 2010). Havzanın güneyinde ise en yüksek noktası $1831 \mathrm{~m}$. olan Aydın Dağları yer almaktadır (Şekil 2). Doğal çevre unsurları şehrin kuruluş alanı ve ulaşım olanaklarını üzerinde doğrudan etkisini göstermektedir. Şehrin Bozdağlar'ın yamacında alüvyon yelpazeleri üzerine kurulması, Küçük Menderes havzasındaki ana ulaşım yollarının Ödemiş'ten geçmesini sağlamıştır. Ulaşım olanakları sayesinde şehrin ticaret fonksiyonu gelişmiş ve bir nevi çevresindeki yerleşmelere oranlara daha fazla merkezileşmiştir. Bu durum şehirde dolaylı olarak dönemsel kalabalıklaşmaya neden olarak suç olaylarını etkilemiştir.

Ödemiş'in şehirsel gelişimde beşeri ve doğal çevre faktörlerinin de etkisi büyüktür. Ödemiş'in tarım ekonomisine sahip bir şehir olması, fiziki yapının doğrudan etkilerini göstermektedir. Ödemiş, şehir olarak birikinti yelpazesi üzerinde, Bozdağ'dan taşınan kolüvyal malzeme üzerine kurulmuştur. Ova tabanından rakım olarak daha yüksekte olması, geçmişte bataklık halinde olan Küçük Menderes nehrinden geçiş yolu üzerinde ve Birgi'ye (Birgi, geçmişte Küçük Menderes Havzasında ki büyük kentlerden birisidir) ulaşım güzergâhında bulunması, Ödemiş'in kuruluşunda ve gelişiminde önemli etki sağlamıştır. Ödemiş'i iç kesimler ile kıyı ticaret alanına bağlayan yolların gelişmesi, İzmir-Aydın demiryolunun Ödemiş'e bağlanması, Ödemiş'i bir pazar 
yeri konumuna getirmiş, ticaret ve pazarlama olanakları şehri bir ticaret şehrine dönüştürmüştür.

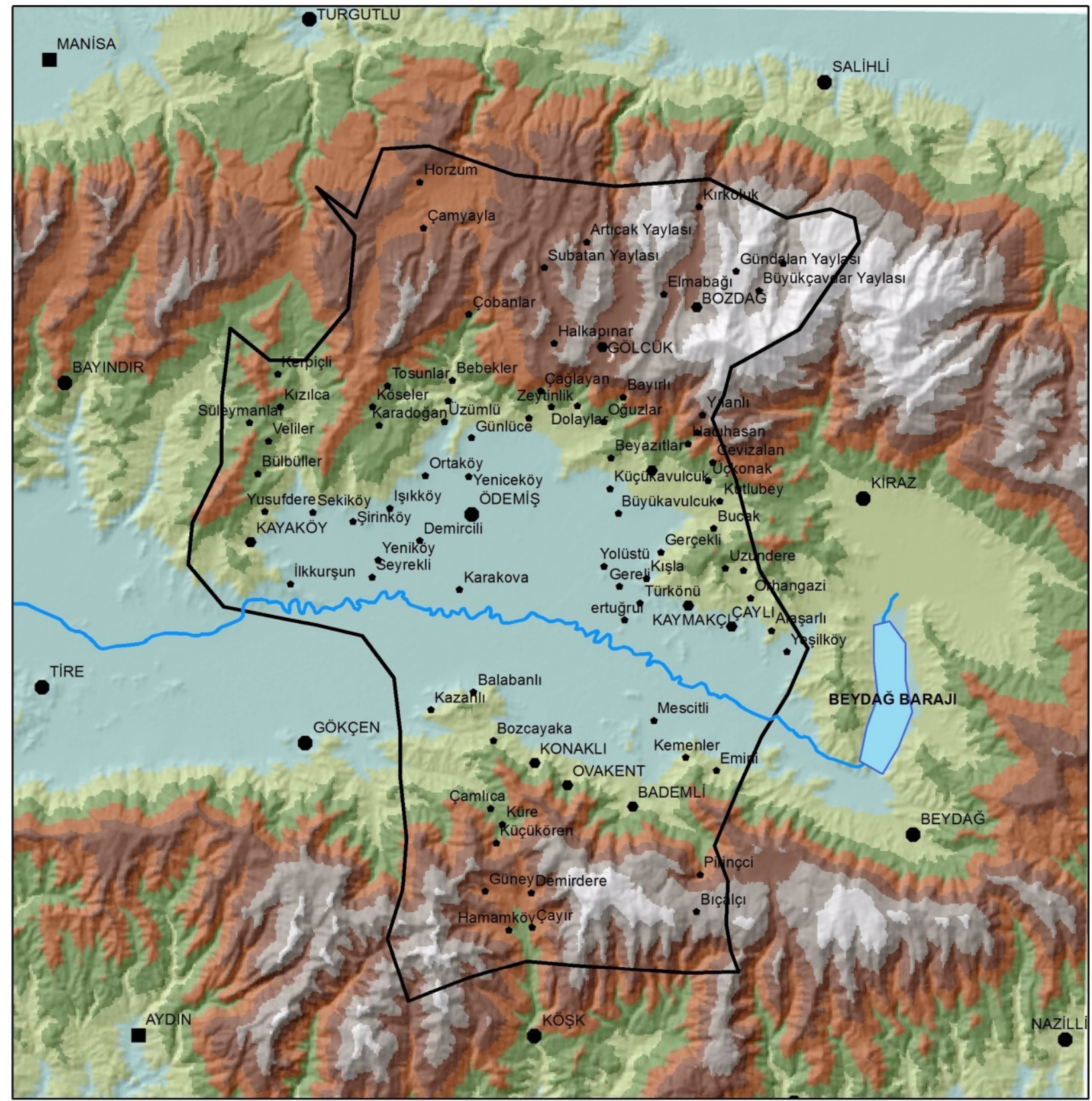

\section{Yerleşmeler}

- il Merkezi

- ilçe Merkezi

- Kasaba

- Köy

Cilçe Sınırı

\section{Su Kaynakları}

Akarsular
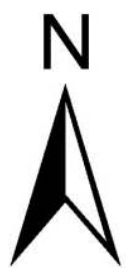

\section{Yükselti (Metre)}

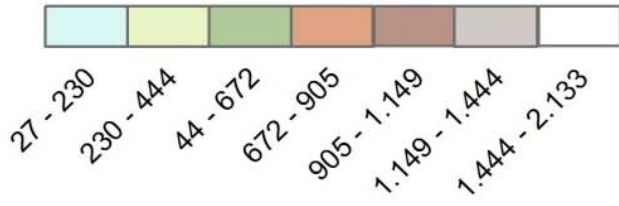

$0 \quad 2,5 \quad 5$

10 20

Şekil 2. Ödemiş ve yakın çevresinin fiziki haritası.

Figure 2. Physical map of Ödemiş and its immediate surroundings. 


\section{BULGULAR}

Şehirler doğaları gereği, farklı sosyal ve mekânsal yapıya sahip yerleşmelerdir. Bu sosyal ve mekânsal yapı farklılıkları ile birlikte şekillenen yaşama biçimi ve günlük faaliyet düzeni, suç olgusunu değişik şekillerde etkilemektedir. Sonuçta suç her yerde görülmekle birlikte, daha çok şehir yerleşmelerinde ortaya çıkan, çok yönlü normal olmayan davranış biçimidir (Aliağaoğlu, 2007). Şehirlerde ortaya çıkan mekânsal ve idari unsurlardan biri de mahallelerdir. Şehirler büyüdükçe mahalle sayıları ve nüfusları artmaktadır.

Ödemiş şehri de mahalle sayısı ve nüfusu bakımından küçük şehirlerle benzer özellikler gösterir. Ödemiş şehrinde en kalabalık mahalleri, Anafartalar, Atatürk, İnönü ve Zafer mahalleleri oluşturmaktadır (Tablo 1, Şekil 3).

Tablo 1. Ödemiş şehrindeki mahalle nüfusları ve suç oranları.

Table 1. Crime rate of hometowns in Ödemiş city.

\begin{tabular}{|l|c|c|}
\hline MAHALELER & NÜFUS & 2012 YILI SUÇLARI \\
\hline Anafartalar & 8895 & 194 \\
\hline Atatürk & 8736 & 296 \\
\hline Inönü & 8617 & 205 \\
\hline Zafer & 8326 & 189 \\
\hline Üç Eylül & 5560 & 175 \\
\hline Türkmen & 5283 & 165 \\
\hline Süleyman Demirel & 5232 & 114 \\
\hline Hürriyet & 4962 & 123 \\
\hline Cumhuriyet & 3925 & 182 \\
\hline Bengisu & 3805 & 110 \\
\hline Umurbey & 3341 & 216 \\
\hline Emmioğlu & 2220 & 105 \\
\hline Akıncılar & 1954 & 217 \\
\hline Kuvvetli & 1642 & 42 \\
\hline Mimar Sinan & 1579 & 41 \\
\hline Meşrutiyet & 1222 & 68 \\
\hline TOPLAM & 75299 & $\mathbf{2 4 4 2}$ \\
\hline
\end{tabular}

Kaynak: TüiK ve Ödemiş ilçe Emniyet Müdürlüğü.

Suçların mahallelere göre dağılışı incelendiğinde Atatürk mahallesinin en fazla suç işlenen mahalle olduğu görülmektedir. Atatürk Mahallesinin suç sayılarının yüksek olması, mahallenin nüfus miktarı ve fonksiyon bakımından gelişmesinden kaynaklanmaktadır. Atatürk mahallesi, şehirdeki en önemli ticaret unsuru olan Cumartesi pazarının kurulduğu mahallelerden birisidir. Ayrıca Çamlık Parkı ve Şükrü Saraçoğlu Stadyumu gibi rekreasyon alanlarını da barındırmaktadır. Endüstri Meslek Lisesi ve Kız Meslek Lisesi bu mahalle sınırları içerisindedir. Saraçoğlu ve Atatürk Caddeleri de şehirde trafik yoğunluğunun ve kazaların fazla görüldüğü caddelerdir. Akıncılar Mahallesi nüfus miktarı bakımından az olmasına rağmen suç sayıları olarak oldukça yüksektir. Cumartesi pazarının büyük bölümü Atatürk Mahallesi ile birlikte Akıncılar Mahallesinde kurulmaktadır. Bu durum Akıncılar Mahallesinde suç oranlarını artırmaktadır (Şekil 5). Şehrin güneyinde bulunan ve suç oranlarının yüksek olduğu Umurbey Mahallesinde sanayi tesisleri yer almaktadır. Sanayi tesislerinin bulunması bu alanda işlenen suçları arttırmıştır. Bu verilerden de anlaşılacağı üzere ticari anlamda hareketliliğin arttığı mahallelerde nüfus ve buna bağlı olarak da suç olayları da artmaktadır.

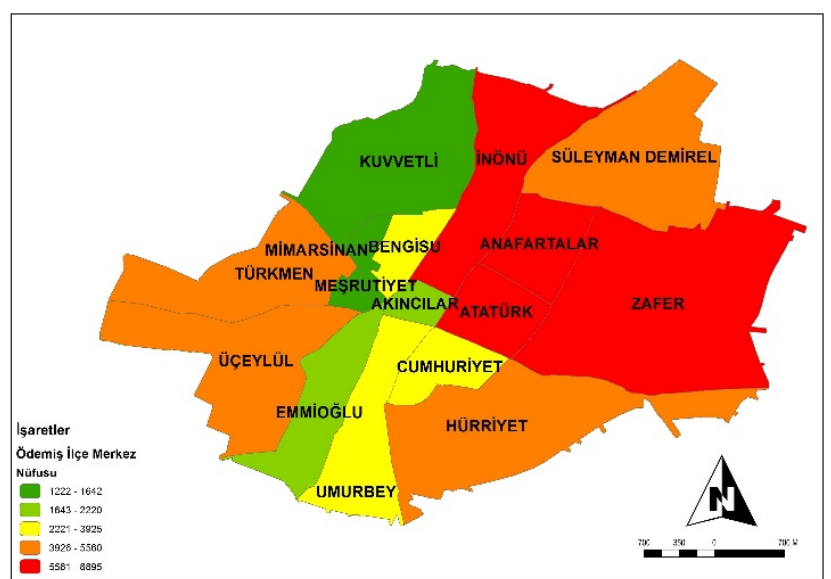

Şekil 3. Ödemiş Şehrinde nüfusun mahallelere göre dağılışı. Figure 3. The distribution of the population according to the neighborhoods in the Ödemiş city

Ödemiş şehrinde iki polis karakol sorumluluk bölgesi bulunmaktadır. Ana hatlarıyla şehrin doğusu Şehit Ayhan Uzun Polis Merkezi (Karakolu), batısı ise Çarşı Polis Merkezi (Karakolu) nin sorumluluk sahası içerisinde yer alır (Şekil 4). Şehrin merkezinde yer alan mahalleler, suç oranlarının yüksek olduğu mahalleler olmakla birlikte doğu kesimindeki mahallelerde suç oranlarının biraz daha fazla olduğunu söylemek mümkündür.

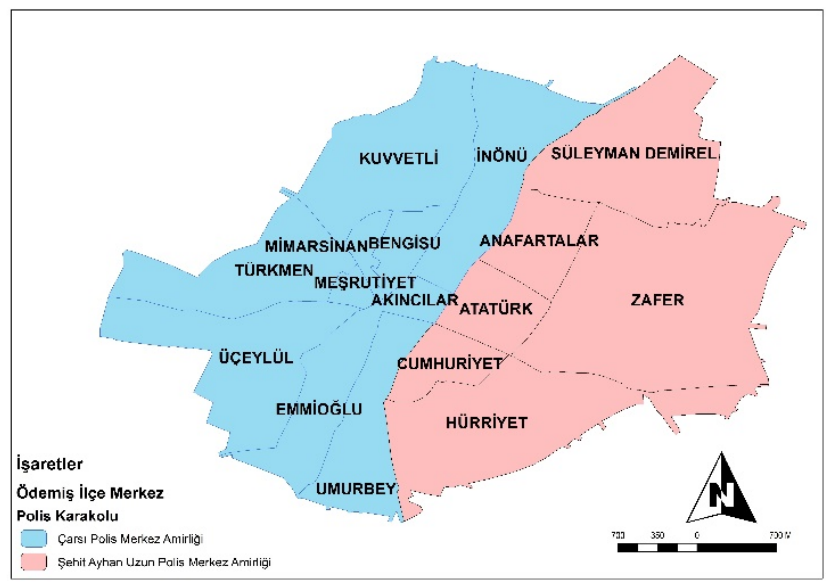

Şekil 4. Ödemiş Şehri'nde polis karakollarının sorumlu olduğu mahalleler.

Figure 4. Police station area responsibity in Ödemiş city.

Ödemiş şehrinde suçlara ilişkin bu genel bilgilerden sonra kişiye karşı işlenen suçları ele almak doğru olacaktır. Şehirde kişiye karşı işlene suçların mala karşı işlenen suçlara 
göre daha fazla olduğunu söylemek mümkündür (Tablo 2). Bu durumu şehirde haftalık olarak kurulan halk pazarları ile açıklamak mümkündür. Cumartesi günleri kurulan halk pazarı, şehirde kalabalıklaşmaya, yaya ve araç trafiğinin artmasına ve bunlara bağlı olarak da suç oranlarının artmasına neden olmaktadır.

Tablo 2. Ödemiş şehrinde suçların dağılışı.

Table 2. Crime distribution of Ödemiş city.

\begin{tabular}{|c|c|c|c|}
\hline Yıllar & Şahsa Karşı Iş̧lenen Suçlar & Mala Karşı Iş̧lenen Suçlar & Toplam \\
\hline 2012 & 1814 & 628 & 2442 \\
\hline 2011 & 1720 & 660 & 2380 \\
\hline 2010 & 1527 & 684 & 2211 \\
\hline 2009 & 1214 & 525 & 1739 \\
\hline 2008 & 1342 & 790 & 2132 \\
\hline 2007 & 1020 & 700 & 1720 \\
\hline
\end{tabular}

Kaynak: Ödemiş il/çe Emniyet Müdürlüğü.

Ödemiş şehrinde kişiye karşı işlenen suçlar, çok fazla suç türü olması nedeniyle, daha kolay anlaşılabilmesi için 4 başık altında toplanacaktır. Bunlar öldürme olayları, yaralama olayları, genel adap ve aile nizamı ile şahıs hürriyeti aleyhinde suçlar ve diğer suçlar olarak gruplandırılmıştır.

Öldürme olayları şehirde eşit bir dağılım göstermiştir. Öldürme suçları mahallelerin fonksiyonel özellikleri ile ilgili değildir. Tüm mahallelerde öldürme olayları görülebilmektedir. Öldürme suçlarının aylık dağılışı incelendiğinde en fazla Öldürme olaylarının ekim ayında gerçekleşmiştir (Tablo 4). Ödemiş şehrinde kişiye karşı işlenen suçlar içinde en yüksek oran, yaralama suçlarına aittir (Tablo 3-4). Yaralama suçlarını kasten yaralama, ihmal ve kazaen yaralama, darp ve yaralamalı trafik kazası olayları şeklinde alt gruplara ayırmak mümkündür. Yaralama suçları içerisinde de en fazla görülen yaralamalı trafik kazası olaylarıdır. Trafik yoğunluğunun fazla olduğu Atatürk, Cumhuriyet ve İnönü mahalleleri, yaralamalı trafik kaza suçlarının en fazla görüldüğü yerlerdir (Tablo 3). Genel olarak yaz ve sonbahar aylarında artan trafik kazalarının kış mevsiminde düştüğü görülür (Tablo 4). Şehirde en az görülen yaralama suçu ise ihmal ve kazaen yaralama suçu durumundadır.

Kişiye karşı işlenen suçlardan bir diğerini genel adap ve aile nizamı ile şahıs hürriyeti aleyhine suçları oluşturur. Bu tür suçlar, kumar oynatma, hakaret ve sövme, çocuk ve kız kadın kaçırma, cinsel suçlar, intihar ve intihara teşebbüs olayları, aile fertlerine kötü muamele ve tehdit olaylarını kapsamaktadır. Bu grupta en fazla görülen suç grubunu intihar ve intihara teşebbüs suçlarıdır. Bu suçlar şehrin genelinde görülmekle birlikte İnönü, Üç Eylül ve Zafer mahallelerinde daha fazla görülür (Tablo 3). İntihara teşebbüs suçlarının buralarda artması, ekonomik durum ile ilişkilendirilebilir.

Ödemiş şehrinde kişiye karşı işlenen diğer suçlar ise narkotik suçlar, mali suçlar ve emniyeti suiistimal suçlarıdır. Bu tür suçlar genel olarak şehrin merkezi durumundaki mahallelerde yoğunlaşır. İş alanlarının ve ticari hareketliliğin şehir merkezinde yoğunlaşması, bu tür suçlarında buralarda artmasına neden olmuştur (Şekil 5).

Tablo 3. Ödemiş şehrinde kişiye karşı işlenen suçların mahallelere göre dağılışı.

Table 3. Crimes against the person distribution in Ödemiş city according to neighborhoods.

\begin{tabular}{|c|c|c|c|c|c|c|c|c|c|c|c|c|c|c|c|c|c|}
\hline ŞAHSA KARŞI İŞLENEN SUÇ & 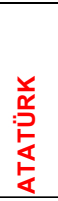 & 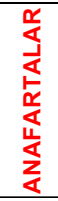 & 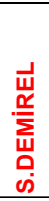 & 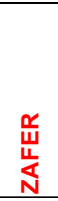 & 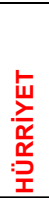 & 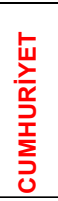 & 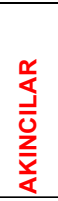 & $\begin{array}{l}: ? \\
: 0 \\
: 0 \\
\underline{z}\end{array}$ & 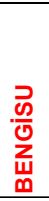 & 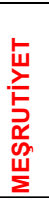 & 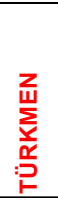 & 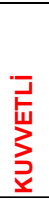 & 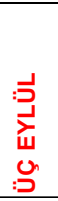 & $\begin{array}{l}z \\
\vdots \\
z \\
\text { w } \\
\Sigma \\
\Sigma\end{array}$ & 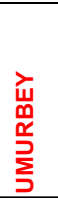 & 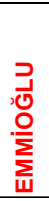 & TOP \\
\hline Kasten Adam Öldürme & 2 & 1 & & & & 1 & & & 1 & & & & 1 & & 1 & & 7 \\
\hline Şüpheli Ölüm & & & & & & & 1 & & 1 & & & & & & & & 2 \\
\hline Ölümlü Trafik Kazası & & & & & & & & & & & 1 & & & & & & 1 \\
\hline Kasten Yaralama & 16 & 11 & 6 & 11 & 9 & 9 & 29 & 22 & 8 & 4 & 21 & 8 & 19 & 4 & 24 & 15 & 216 \\
\hline Kasten Yaralama (Darp) & 50 & 16 & 6 & 16 & 10 & 20 & 16 & 10 & 1 & & 9 & & 6 & 2 & 11 & 4 & 177 \\
\hline Taksirle Yaralama İhmalen & 5 & 2 & 7 & 2 & 2 & 5 & 5 & 3 & 3 & 1 & 6 & & 4 & 2 & 5 & 3 & 55 \\
\hline 6136 S.K.M & 2 & 6 & & 5 & 2 & 4 & 3 & 2 & 2 & 1 & 4 & & 5 & 4 & 3 & 2 & 45 \\
\hline Meskun Mahlde Silah Atmak & & & & 1 & & 2 & & & & 2 & 2 & & 1 & & & & 8 \\
\hline Kız, Kadın, Erkek Kaçırma & 1 & 1 & & & & 2 & 1 & 1 & 1 & 2 & 1 & & 1 & & 1 & & 12 \\
\hline Çocuk Kaçırma & & & & & & & 1 & 1 & & & & & 1 & & 1 & 1 & 5 \\
\hline Cinsel Suçlar & & 1 & & 1 & & & & & 2 & & & & & 1 & & & 5 \\
\hline İntihar & & & & 1 & & & 1 & & & & & & & & 1 & 1 & 4 \\
\hline İntihara Teşebbüs & 11 & 10 & 12 & 16 & 12 & 7 & 10 & 15 & 8 & 5 & 8 & 4 & 13 & 6 & 8 & 7 & 152 \\
\hline Kumar Oynama-Oynatma & & & & & & 3 & & & & & & & & & & 2 & 5 \\
\hline Aile Fertlerine Kötü Muamele & 3 & 5 & 4 & 11 & 4 & 6 & 5 & 6 & 1 & & 10 & & 6 & 1 & 9 & 1 & 72 \\
\hline Kayıp Şahıslar & 10 & 6 & 4 & 3 & 3 & 4 & 2 & 6 & 12 & 4 & 12 & 5 & 10 & & 3 & 2 & 86 \\
\hline Hakaret-Sövme & 16 & 22 & 3 & 13 & 5 & 8 & 9 & 7 & 9 & 5 & 12 & & 7 & 3 & 11 & 5 & 135 \\
\hline Tehdit & 35 & 16 & 4 & 11 & 5 & 13 & 16 & 15 & 6 & 7 & 7 & 2 & 14 & 2 & 18 & 12 & 183 \\
\hline Fuhuş Suçları & & & & & & & & & & & & & & & 1 & & 1 \\
\hline Taksirle Yaralama ( Trf.Kaz.) & 34 & 23 & 18 & 24 & 25 & 33 & 19 & 31 & 6 & 7 & 21 & 7 & 18 & 3 & 26 & 15 & 310 \\
\hline Bilişim Şuçları & & 1 & 1 & 2 & 1 & & 1 & & 1 & & 1 & & & & & & 8 \\
\hline İş Kazası & 1 & 5 & 4 & 2 & 3 & & 3 & 2 & & 1 & & & 1 & & 7 & 5 & 34 \\
\hline Mali Kaçakçılık & 1 & & & & 1 & 1 & & & 2 & & & & & & 2 & & 7 \\
\hline Narkotik Olayları & 3 & & 1 & 2 & 3 & 3 & 2 & 4 & 1 & 1 & 3 & & 7 & 2 & 4 & 1 & 37 \\
\hline Mali Şube Olayları & 2 & 2 & & & & 1 & 3 & 3 & 6 & 3 & 1 & 1 & 3 & 2 & 12 & 1 & 40 \\
\hline Emniyeti Suistimal & 4 & 1 & & & & 3 & 6 & 3 & & & 2 & 2 & 1 & & 4 & & 26 \\
\hline Tasnif Dışı & 23 & 20 & 5 & 16 & 6 & 12 & 20 & 18 & 16 & 5 & 13 & 5 & 15 & & 5 & 2 & 181 \\
\hline TOPLAM & 219 & 149 & 75 & 137 & 91 & 137 & 153 & 149 & 87 & 48 & 134 & 34 & 133 & 32 & 157 & 79 & 1814 \\
\hline
\end{tabular}

Kaynak: Ödemiş illçe Emniyet Müdürlüğü. 
Coğrafi bakış açısıla Ödemiş şehrinde kişiye karşı işlenen suçlar

Tablo 4. Ödemiş şehrinde kişiye karşı işlenen suçların aylara göre dağılışı.

Table 4. Crimes against the person distribution in Ödemiş city according to months.

\begin{tabular}{|c|c|c|c|c|c|c|c|c|c|c|c|c|c|}
\hline \multicolumn{14}{|c|}{2012 YILI ÖDEMiŞ ŞEHRI'NDE iŞLENEN SUÇLARIN AYLIK DAĞILIŞI } \\
\hline Şahsa Karşı İşlenen Suçlar & OCA & ŞUB & MAR & Nis & MAY & HAZ & TEM & AĞS & EYL & EKM & KAS & ARL & TOP \\
\hline Kasten Adam Öldürme & & 1 & & 1 & & & 1 & & & 3 & 1 & & 7 \\
\hline Şüpheli Ölüm & 1 & & & & & & 1 & & & & & & 2 \\
\hline Ölümlü Trafik Kazası & & & & & & & 1 & & & & & & 1 \\
\hline Kasten Yaralama & 10 & 12 & 14 & 19 & 18 & 26 & 28 & 19 & 15 & 21 & 8 & 26 & 216 \\
\hline Kasten Yaralama (Darp) & 4 & 13 & 10 & 18 & 12 & 14 & 21 & 21 & 18 & 25 & 11 & 10 & 177 \\
\hline Taksirle Yaralama İhmalen & 4 & 2 & 2 & 6 & 4 & 10 & 9 & 3 & 4 & 5 & 3 & 3 & 55 \\
\hline 6136 S.K.M & 4 & 9 & 2 & 4 & 3 & 1 & 2 & 8 & 5 & 2 & 1 & 4 & 45 \\
\hline Meskun Mahlde Silah Atmak & & 1 & & & 1 & & & 3 & 2 & 1 & & & 8 \\
\hline Kız, Kadın, Erkek Kaçırma & 2 & & 1 & & 1 & & 1 & 2 & 4 & & & 1 & 12 \\
\hline Çocuk Kaçırma & & & 2 & 1 & & & 1 & 1 & & & & & 5 \\
\hline Cinsel Suçlar & & 2 & & 1 & & 1 & 1 & & & & & & 5 \\
\hline İntihar & 1 & & & & 1 & & & & 2 & & & & 4 \\
\hline İntihara Teşebbüs & 11 & 11 & 6 & 12 & 14 & 15 & 16 & 18 & 18 & 15 & 10 & 6 & 152 \\
\hline Kumar Oynama-Oynatma & & 1 & & & 1 & & & & 1 & & 1 & 1 & 5 \\
\hline Aile Fertlerine Kötü Muamele & 3 & 3 & 5 & 8 & 7 & 8 & 6 & 8 & 6 & 6 & 5 & 7 & 72 \\
\hline Kayıp Şahıslar & 4 & 7 & 5 & 11 & 12 & 5 & 6 & 10 & 3 & 10 & 6 & 7 & 86 \\
\hline Hakaret-Sövme & 12 & 12 & 11 & 12 & 7 & 11 & 19 & 19 & 13 & 12 & 3 & 4 & 135 \\
\hline Tehdit & 10 & 12 & 17 & 15 & 16 & 11 & 15 & 18 & 23 & 20 & 14 & 12 & 183 \\
\hline Fuhuş Suçları & & & & & & & & & & & & 1 & 1 \\
\hline Taksirle Yaralama ( Trf.Kaz.) & 18 & 20 & 20 & 25 & 33 & 23 & 30 & 29 & 38 & 26 & 29 & 19 & 310 \\
\hline Bilişim Şuçları & & 1 & & & 1 & 2 & 3 & 1 & & & & & 8 \\
\hline İş Kazası & 1 & 4 & & 3 & 9 & 1 & & 7 & 4 & 2 & 2 & 1 & 34 \\
\hline Mali Kaçakçılık & & 2 & 1 & & 1 & & & 1 & 1 & 1 & & & 7 \\
\hline Narkotik Olayları & 3 & 5 & 4 & 1 & 4 & 2 & 4 & 1 & 4 & 6 & 3 & & 37 \\
\hline Mali Şube Olayları & 5 & 8 & 5 & 3 & 2 & 3 & 1 & 5 & 2 & 2 & 3 & 1 & 40 \\
\hline Emniyeti Suistimal & 3 & 3 & 2 & 2 & 3 & 2 & 1 & 3 & 1 & 3 & 2 & 1 & 26 \\
\hline Tasnif Dışı & 16 & 20 & 17 & 9 & 16 & 20 & 14 & 10 & 16 & 11 & 16 & 16 & 181 \\
\hline Toplam & 112 & 149 & 124 & 151 & 166 & 155 & 181 & 187 & 180 & 171 & 118 & 120 & 1814 \\
\hline
\end{tabular}

Kaynak: Ödemiş ilç̧e Emniyet Müdürlüğü.

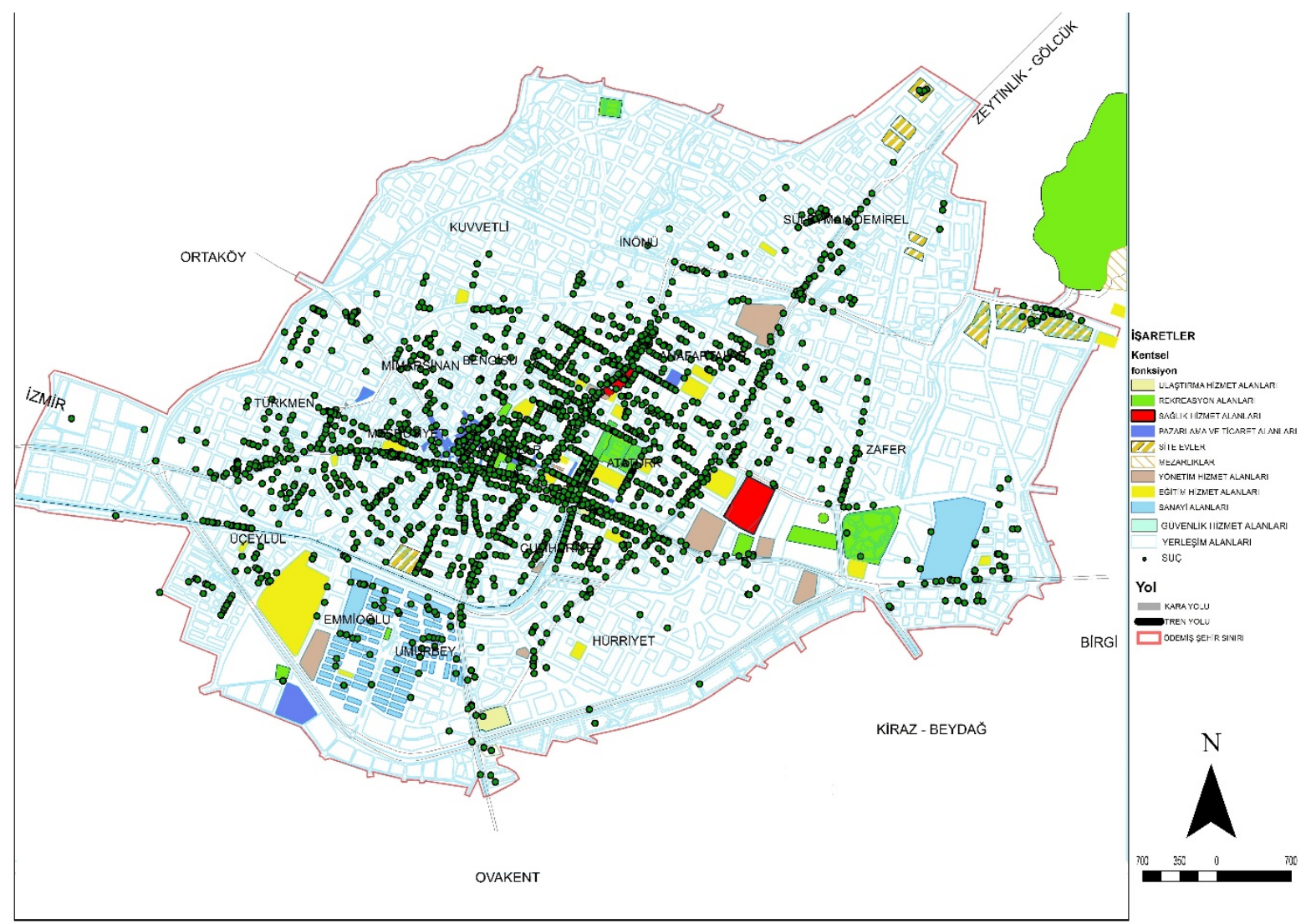

Şekil 5. Ödemiş şehrinin kentsel fonksiyonları ve suçların dağııışı.

Figure 5. Urban Function of Ödemiş and distribution of crimes. 
Şahsa karşı işlenen suçların aylara göre dağılımı incelendiğinde yaz mevsiminde arttığı, kış mevsiminde ise azaldığı görülmektedir (Tablo 4, Şekil 6). Kişiye karşı işlenen suçlar mahalle ölçeğinde incelendiğinde pazar yeri, sanayi, okul sayısı, rekreasyon alanları göz önünde bulundurularak suçların genel olarak Akıncılar, İnönü, Anafartalar, Atatürk, Umurbey ve Üç Eylül mahallerinde arttığı görülmektedir (Tablo 3).

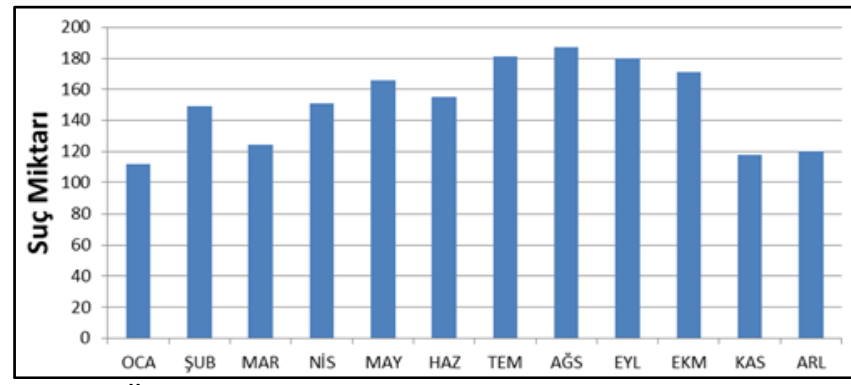

Şekil 6. Ödemiş şehrinde kişiye karşı işlenen suçların aylara göre dağılışı (2012 yılı).

Figure 6. Crimes against the person distribution in Ödemiş city according to months (2012).

\section{SONUÇ ve TARTIŞMA}

Ödemiş toplam suç sayısı bakımdan İzmir ilinin taşra ilçeleri arasında ikinci sırada yer almaktadır. Suç coğrafyasında merkezileşme artıkça suç sayıları artış göstermektedir. Suçların bir çekirdek etrafında yayıldığı düşünüldüğünde, en fazla suçların işlendiği ilçeler olarak Menemen ve TorbaIı, İzmir'e daha yakın kentlerdir. Ödemiş'in İzmir'e olan uzaklığı düşünüldüğünde suçların daha düşük olması beklenilmektedir. Fakat Ödemiş ve çevresinin de ekonomik faaliyetler nedeniyle merkezileşmiş alan olması bu varsayımı çürütmektedir.

Ödemiş Şehri'nin bazı coğrafi özellikleri suçların tür ve dağılışında önemli etkileri vardır. İklim ve iklim elemanları suçların mevsimsel dağılımında etkileri söz konusudur. Ödemişte kişiye karşı işlenen suçlar, yaz mevsiminde artış göstermektedir. Diğer bir grup olan mala karşı işlenen suçlar, kış mevsiminde artış göstermektedir. Ödemiş'in nüfus ve yerleşme özellikleri suç dağılışında etki eden diğer faktörlerdir. Şehrin fonksiyon alanları ile kişiye karşı suçların dağılışı arasında paralellik gözlemlenmiştir. Şehrin ticaret alanları suçların çekim merkezi olmuştur. Özellikle Cumartesi pazarının kurulduğu Atatürk ve Akıncılar Mahallelerinde kişiye karşı suçlar artış göstermektedir.

Ödemiş şehri çevresi tarım ve hayvancılıktan gelen zenginliğini, şehrin ticaret, ulaşım, sanayi vb. fonksiyonlarını ekleyerek kentsel gelişimini sürdürmektedir. Şehrin sosyolojik özelliklerinden kaynaklanan suç olgusu, şehrin gelişimiyle birlikte artış içerisindedir. Şehirde kişiye karşı suçların artışını önlemek için çeşitli önlemelerin alınması gerekmektedir. Güvenlik birimlerinin suçun yoğunlaştığı gün ve lokasyonlarda alacakları çeşitli önlemlerle şehirde kişiye karşı işlenen suçların azalacağı düşünülmektedir.

\section{KAYNAKLAR}

Aliağaoğlu, A. (2007). Balıkesir Şehrinde Suçlar: Coğrafi Bir Yaklaşım (2005), Detay Yayıncılık, Ankara.

Andris, A. (1997). Applied Climatology: Principles and Practice, "Comfort, Clothing and Heath", Routledge, London.

Davidson, N. (1999). "Crime and Fear of Crime", Appliedgeography: principles and practice, An introductian to useful research in physical, environmental and human geography, s. 438-449.

Dönmezer, S. (1994). Kriminoloji, Beta Yayıncılık, İstanbul.

Erem, F. (1997). Ceza Hukuku (Genel Hükümler), Seçkin Yayınevi, Ankara.

Gözenç, S. (1978). Küçük Menderes Havzasında Arazinin Kullanılış Ve Sınıflandırılması, İstanbul Üniversitesi Yayınları No:2396 Coğrafya Enstitüsü Yayınları No:94, İstanbul.

Herbert, D. T., Hyde, S. W., (1985). Environmental Criminology: Testing Some Area Hypotehesis, Transactions of The Institite Of British Geographers, New Series, Vol. 10, No. 3,259-274.

İçli, T. G. (1999). Kriminoloji, Bizim Büro Basımevi, Ankara.

İçli, T. G. (2013). Kriminoloji, Hukuk Kitapları Dizisi, Sekizinci Baskı, Seçkin Yayıncılık, Ankara.

Karakaş, E. (2005). Uygulamalı Coğrafyada Suç Haritaları I: Veri Kaynakları, Fırat Üniversitesi Sosyal Bilimler Dergisi, Cilt:15, Sayı:1, 57-69, Elazı̆̆.

Özey, R. (2004). İnsan Davranışları, Hukuk, Güvenlik, Suç Ve Coğrafya, Emniyet Genel Müdürlüğü, Polis Dergisi, 159. Yıl Özel Sayı 39, 386-393, Ankara.

Sargın, S., ve Temurçin, K. (2011). Türkiye'nin Suç Coğrafyası: Şehir Asayiş Suçları, Polis Akademisi Yayınları, Ankara.

Tümertekin, E., (1984). Ekonomik Coğrafya, İstanbul Üniversitesi Edebiyat Fakültesi Yayınları No.2926, İstanbul.

Vardar, S. (2010). Birgi ve Küçük Menderes Vadisinin Jeomorfolojisi, Küçük Menderes Araştırmaları Makaleler, Çekül Vakfı / Küçük Menderes Araştırmaları Merkezi Yayını, No:1,s. 6-22, İzmir.

Yılmaz, Z. (2006). Anayasa TCK-CMK Infaz Kanunu. Seçkin Yayınevi, Ankara. 